\title{
Controlled lysimetric simulation of accidents giving rise to radioactive pollution of the agricultural environment: Synthetic overview of research carried out at IPSN
}

\author{
F. BRÉCHIGNAC ${ }^{1}$, C. MADOZ-ESCANDE ${ }^{1}$, M.A. GONZE ${ }^{1}$, E.H. SCHULTE ${ }^{2}$
}

(Manuscript received 12 February 2001, accepted 30 May 200I)

ABSTRACT The consequences of a severe nuclear accident on the agricultural environment, releasing ${ }^{137} \mathrm{Cs}$ and ${ }^{90} \mathrm{Sr}$-enriched aerosols, have been studied within an original lysimetric facility driven in controlled conditions. Focal point of a research scope widely open to European collaborations, this facility has hosted several scientific programmes spread over about a decade (RESSAC and PEACE, notably), the principal achievements of which are provided in the form of a synthetic overview. After a brief reminder of the historical context strongly challenged by the Chernobyl accident within which this project has evolved, the originality of the instrumental set up used for simulating a nuclear accident at a small scale is presented. The addressed scientific aspects concern the clarification of radioecological mechanisms governing the behaviour of these two radionuclides in the soil-plant system. A particular focus is placed on foliar transfers and the resulting translocation, soil in-depth migration, chemical composition of the soil interstitial water, the influence of the later on root absorption which determines the soil-to-plant transfer, all aspects being stressed over a representative spectrum of plants, soil and climates. Based on a strategy of synergy between experiments and modelling developments, the achievements obtained are used to improve the predictive radioprotection tools.

RÉSUMÉ Simulation contrôlée sur lysimètres d'accidents donnant lieu à une pollution radioactive de l'environnement agricole : bilan synthétique des recherches menées à l'IPSN.

Les conséquences sur l'environnement agricole d'un accident nucléaire grave, produisant un rejet d'aérosols chargés en ${ }^{{ }^{37}} \mathrm{Cs}$ et ${ }^{90} \mathrm{Sr}$, ont été étudiées au moyen d'une installation lysimétrique originale conduite en conditions contrôlées. Point focal de recherches largement ouvertes à des collaborations européennes, cette installation a abrité le déroulement de plusieurs programmes scientifiques étalés sur près d'une décade (RESSAC et PEACE, notamment) dont un bilan synthétique des principaux enseignements est dressé. Après un bref rappel historique du contexte fortement marqué par l'accident de Tchernobyl dans lequel ce projet a grandi, l'originalité du dispositif instrumental mis en ouvre pour simuler un accident nucléaire à une échelle réduite est présentée. Les aspects scientifiques abordés

\footnotetext{
Institut de protection et de sûreté nucléaire, Département de protection de l'environnement, Service d'études et de recherches radioécologiques de laboratoire, Centre d'études de Cadarache, BP I, 13108 Saint-Paul-lez-Durance, France.

${ }^{2}$ European Commission, Directorate General for Research DII, Safety and Management of the fissile fuel cycle, Radiological protection, 200 rue de la Loi, 1049 Brussels, Belgium.
} 
concernent la clarification des mécanismes radioécologiques qui sous-tendent le comportement de ces deux radionucléides dans le système sol-plante. II s'agit en particulier des transferts foliaires et de la translocation résultante, de la migration dans les sols, de la composition chimique de l'eau interstitielle du sol, de son influence sur l'absorption racinaire qui détermine le transfert sol-plante, aspects tous abordés sur un spectre de plantes, de sols et de climats représentatifs. Utilisant une stratégie de synergie entre expérimentations et modélisation, les acquis sont intégrés dans une amélioration des outils prédictifs mis au point pour la radioprotection.

\section{Introduction - Historical context}

To gain better knowledge of the environmental consequences of a severe nuclear accident, releasing radioactive aerosols into the atmosphere, led to the development, since 1985, of an instrumental concept at IPSN capable of laboratory simulation of real, although miniaturised, radioactive contamination of cultivated agricultural soils (Grauby, 1988; Legrand, 1988). The Chernobyl accident in the following year, in 1986, reinforced the relevance of the subject. From then on, under media pressure, the scientific project that was then under study became more directed towards the problems of rehabilitation of contaminated surfaces using in situ experiments - hence the name "RESSAC": Réhabilitation des Sols et des Surfaces en cas d'Accident (soil and surface rehabilitation further to accidents) rather than towards problems of transfer to man via agricultural production. This in situ facet of the RESSAC programme has examined, in particular, the potential of several soil decontamination-rehabilitation techniques (Jouve et al., 1991, 1992, 1993, 1994; Legrand et al., 1989; L'Homme et al., 1989; Maubert et al., 1991, 1992, 1993; Renaud and Maubert, 1997).

The lysimetric facility construction under controlled greenhouses was undertaken alongside in this context. The installation became operational in 1993 having obtained the administrative authorisation conferring the status of ICPE (Installation Classée pour la Protection de l'Environnement, classified facility for environmental protection), which gave it the liability to undertake "in active mode" experimental simulations. Lysimeter contamination was undertaken in 1994 and completed at the beginning of 1995 . On the technical side, the facility was designed to

(1) simulate accidental contamination, by release of radioactive aerosols containing ${ }^{137} \mathrm{Cs}$ and ${ }^{90} \mathrm{Sr}$, in plots of land representing agricultural soil, and,

(2) to follow up and quantify, in the long term and under controlled weather conditions, the evolution of this contamination both in the soil and cultivations that followed. 


\section{Programme performance and orientation}

\subsection{First phase: RESSAC programme (3rd FP, 1992-1995)}

The laboratory facet (lysimeters) of the RESSAC programme was undertaken with the dual assistance of EDF and the CEC under the auspices of the 3rd Framework Programme (1992-1995), which enabled the project to be set into a European collaboration $^{13}$. This first phase was dominated by the extensive preparation of the simulation experiments that mobilised most of the efforts. This preparation was conducted on several parallel fronts:

(1) the implementation of the study devices: the lysimeters (selection of soil sampling sites, soil monolith sampling and implementation of the lysimetric systems, lysimeter instrumentation, layout in the greenhouses, etc.),

(2) the operational implementation of the POLYR contamination device (study and characterisation of aerosols released),

(3) the prerequisite agronomical verifications for the correct operation of the controlled lysimeter climate assembly (prerequisite cultivation campaigns "in cold mode", verifications of rain control and hydrological follow up of the soils, etc.).

The investigations were first of a technical and agronomical nature to finally lead to radioecology, from 1994-1995 when the accidental contamination simulations on 7 lysimeters were performed. This first programme was completed with the study of foliar transfers observed during the first months immediately following contamination.

\subsection{Second phase: New programme design (1996)}

The numerous in situ studies incited by the Chernobyl accident showed that ${ }^{137} \mathrm{Cs}$ and ${ }^{90} \mathrm{Sr}$ contamination of agro-ecosystems intended for food production significantly contributes to the dose of radiation received by the populations (Strand et al., 1996). Therefore, limitation of this risk by means of early decisions and appropriate management of contaminated agricultural surfaces, mainly rests on our capacity to predict, using models, how and on what scale, initial contamination may be transferred in the agricultural productions polluted by it. In addition to this, the prediction model's efficiency depends on our level of

\footnotetext{
Mol Nuclear Rescarch Centre, Radioecological Laboratory (Belgium); University of Barcelona, Plant Biology Laboratory (Spain); Jülich KFA Radioagronomy Laboratory (Germany); the Atomic Energy Authority, Harwell UKAEA (Great Britain); the "Centro de Investigaciones Energéticas. Medioambientales y Technológicas", CIEMAT (Spain); the Gembloux Agronomy Science Faculty (Belgium) and the University of Athens (Greece).
} 
understanding of the mechanisms governing the transfer of radionuclides in the soil-plant system.

However, it appeared at that time that the attainment of such understanding from the in situ observations alone of environmental contaminations linked to past events (i.e. Chernobyl) was difficult for two crucial reasons:

(1) the accidental situation inferred that the contamination characteristics were neither well known, nor controlled, as they occurred under critical conditions,

(2) the large spatial and time variability of the natural environment is beyond control and this obstructs clear identification of parameters influencing the transfer of radionuclides.

It is this thinking line which leads to the development of a radically new programme, both in terms of its contents as well as its international organisation ${ }^{42}$. Its main objective was to improve the knowledge of transfer mechanisms in the soil-plant system by means of a laboratory approach, under well-controlled conditions, such as those offered by the lysimetric facility. While this programme called PEACE (Programme d'Études Agronomiques sur les Accidents Contaminant l'Environnement, programme for evaluating the impact of accidents contaminating the environment) was submitted to the CEC before being accepted within the scope of the 4th Framework Programme, the first studies concerning vertical migration in soil and root transfer to barley and vine plants were implemented.

\subsection{Third phase: PEACE programme (4th FP, 1997-1999)}

Going beyond the sole quantification of traditional radioecological values (transfer factors), this programme was dominated by research for better understanding of the mechanisms that govern the behaviour of radioactive pollutants in soils and in plants by root absorption. The objective followed up may be broken down into two complementary frameworks:

(1) to reach a better understanding of key, biological and physico-chemical, processes governing radionuclide flux in the soil-plant system,

(2) to feed the development and validation of mechanistic models, using controlled experimental data, that describe ${ }^{137} \mathrm{Cs}$ and ${ }^{90} \mathrm{Sr}$ transfer in the soil-plant system, in such a manner as to lead to improvements of predictive performances for global models used in radioprotection.

\footnotetext{
42 Mol Nuclear Research Centre, Radioecological Laboratory (Belgium); University of Barcelona, Plant Biology Laboratory (Spain); the London Imperial College of Science, Technology and Medecine (Great Britain) and the Swedish Agriculture University of Uppsala (Sweden).
} 
In order to achieve this, a dual experimentation and modelling procedure is implemented, designed and conducted in strict collaboration.

Three converging research lines are undertaken:

- clarification of soil-radionuclide relationships, concentrated on:

(1) the dynamic study of the chemical composition of the ground water, with, in particular, the influence of soil moisture,

(2) the kinetic description of vertical migration profiles of radionuclides in the soil;

- the quantified description of the variability of soil-to-plant transfers resulting from a certain number of factors such as soil type, agricultural practices, the hydrological regime, and the time elapsed since contamination;

- the analyses of this data to adapt, improve and validate mechanistic models of vertical migration and of root absorption.

\section{Technical overview}

\subsection{Controlled lysimetric facility under greenhouse}

A detailed description of the facility having been given by Bréchignac et al. (1996), Bréchignac et al. (1997), completed by Madoz-Escande et al. (1999), only the main features are summarised in the following.

\subsubsection{The instrumental concept and its infrastructure}

The facility is a depressurised laboratory of around $2000 \mathrm{~m}^{2}$ comprising 4 greenhouses inside which predefined climate (temperature, hygrometry, light radiation) and hydrological conditions (rain) can be artificially simulated using computer based real time automatic regulations. Each greenhouse can house 3 lysimeters comprising block sample soil monoliths (12 tons) without destroying the natural pedological stratification. Each lysimeter is instrumented to simulate the in-depth presence of a ground water table, by means of a porous bed (ceramic) directly mounted onto a water tank (Fig. 1). This unique system enables in-depth control of soil moistening. The underground part of the lysimeters is installed in a single hall where the temperature is controlled independently from the greenhouses. The upper sides of each lysimeter presenting surfaces that may be cultivated $\left(4 \mathrm{~m}^{2}\right)$ are mounted against the greenhouse floor such as to open up at the upper part of the laboratory (Fig. 2). The lysimeters are installed in the greenhouses which are each subjected to a standard average climate. 


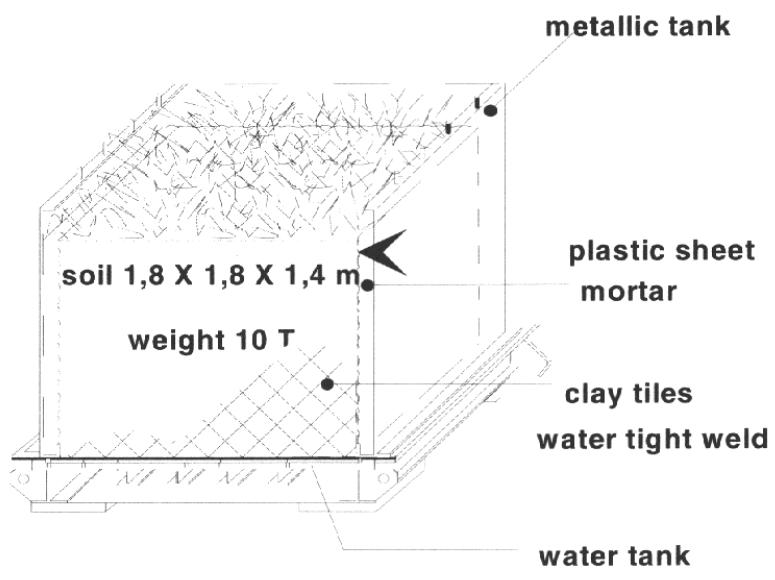

Figure 1 -Scheme of a soil monolith set up in a lysimeter.

Schéma éclaté d'un monolithe de sol installé dans un lysimètre.

01 Greenhouse

02 Radioactive aerosol generation

03 Terphane envelope

04 Induction furnace

05 Lysimeter

06 Soil monolith

07 Metallic casing

08 Porous ceramic bottom layer

09 Control electronic bay

10 Water reservoir

11 Cement

12 Polyethylene envelope

(01)

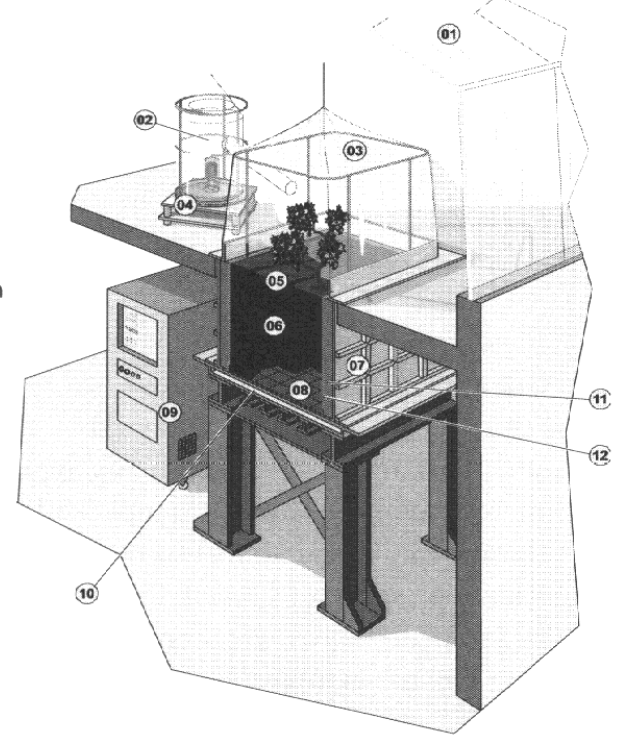




\subsubsection{Climate control}

The average climate characteristics corresponding to the soil sampling sites were used to construct three standard climates (Mediterranean, continental-oceanic and continental). Standard climates are artificially reproduced, with seasonal and nyctemeral variations, by automatic computerised control. The temperature and hygrometry corresponding to each of these three climates are artificially reconstructed in three independent greenhouses. The intensity of light radiation is correctly reproduced during the winter months, but is deficient during the summer months (typical problem in greenhouses) despite the addition of artificial lighting. Different soils were regrouped under each greenhouse in order to profit from a standard climate nearest the real original conditions. Rain simulators enable each soil to be subjected to rainfalls corresponding to the averages recorded in situ at the sampling sites.

\subsubsection{Accidental simulation and contamination of lysimeters}

The simulation of an accidental contamination is performed using an induction oven (POLYR) that produces aerosols similar to those that would be released into the environment following a severe malfunctioning occurring in a PWR reactor with core melt down (around $3000{ }^{\circ} \mathrm{C}$ ). Aerosols are produced in an atmosphere that is saturated with water and confined in a polyethylene envelope that may be interconnected to a similar envelope covering the lysimeters surface that is to be contaminated (Fig. 3). They are produced from a mix of elements representing materials that comprise a $900 \mathrm{MW}$ reactor core: the fuel (uranium oxide), the core structure materials, the sheath and the control bars components. Respective proportions correspond to the quantities of the core inventory, reduced by a factor of $10^{7}$. The two fission products that are most harmful for the environment, ${ }^{137} \mathrm{Cs}$ and ${ }^{90} \mathrm{Sr}$, are included in this experimental mixture. The aerosols are produced by increasing this mixture's temperature, in powder form, up to a temperature of $2950^{\circ} \mathrm{C}$, which is reached 30 minutes later and is maintained for 15 minutes.

The experimental protocol begins with the contamination of each lysimeter that gives rise to the deposit of aerosols on each soil and its cultivation. These initial cultivations are then followed up and are annually replaced according to a predefined rotation, the soil and plant contamination levels are regularly examined for several successive years.

\subsection{Preparation of experimental simulations}

\subsubsection{The soil in the lysimeters}

The soil sampling sites were chosen to represent both the most common pedological types in Western Europe and the zones of the highest associated risk 


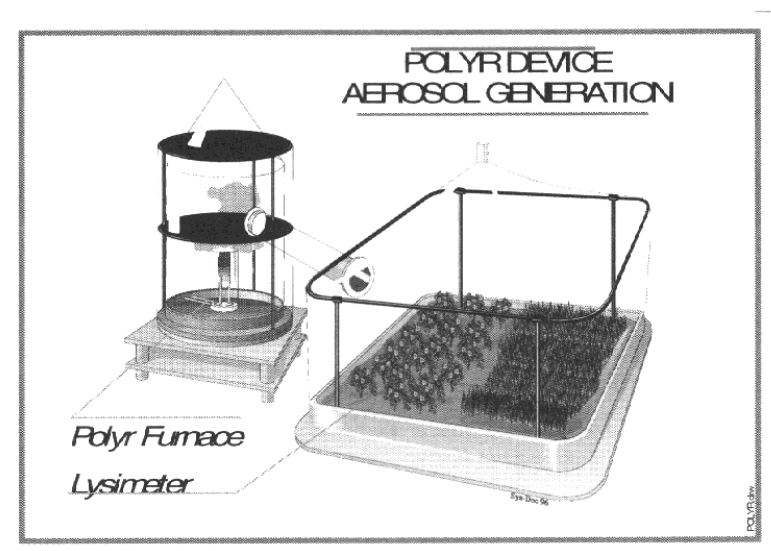

Figure 3 - Assembly used for experimental simulation of accidental radioactive contamination featuring the aerosol-generating device (POLYR furnace, left) and the lysimeter surface (right).

Assemblage utilisé pour la simulation expérimentale de contaminations radioactives, avec le dispositif de production d'aérosols (four POLYR, à gauche) et la surface d'un lysimètre (à droite).

due to the local presence of nuclear facilities. These were the Mol (Belgium), Jülich (Germany), Barcelona (Spain), Wellesbourne (England), Belleville and Tricastin (France) sites for which climatic, pedological and hydrological data for the soils have also been carefully recorded.

After monolith soil samples were taken using excavation, they were moved to Cadarache, then installed in the lysimetric cases with a hydrological control system, and finally installed in the greenhouses (Fig. 4). All together, 7 monoliths were taken and installed in the facility. The detailed physico-chemical characteristics of the soil were determined both in situ and on the monolith samples taken, without any appreciable difference. This is outlined in Table I.

A preliminary characterisation of the soil-radionuclides interaction featured the comparison of chemical availability of ${ }^{137} \mathrm{Cs}$ and ${ }^{90} \mathrm{Sr}$ according to which the latter were introduced in ionic form or in aerosol form (produced using the contamination device POLYR). If the chemical availability of radiocaesium remained identical in both cases, even after 5 months of ageing, the radiostrontium introduced in aerosol form displayed less availability which then increased with the ageing time.

The originality of the implemented lysimetric system rests in the simulation of the deep water exchanges, as this is performed in situ from the ground water table. 

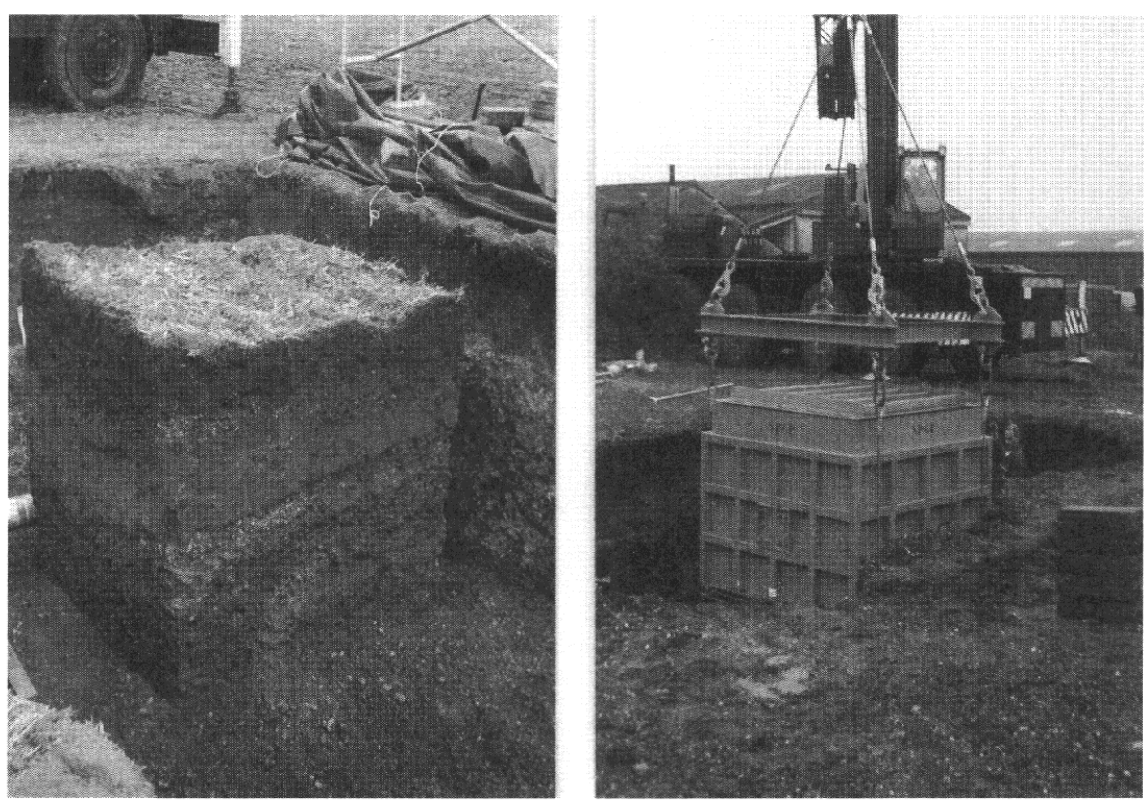

Figure 4 - Soil monolith in situ sampling by excavation.

Extraction in situ par excavation d'un monolithe de sol.

\section{TABLE I}

Main physico-chemical characteristics of the various soils in the plough layer.

Principales caractéristiques physico-chimiques des différents sols dans la zone labourée.

\begin{tabular}{|c|c|c|c|c|c|}
\hline $\begin{array}{l}\text { Geographical } \\
\text { sampling site }\end{array}$ & $\begin{array}{c}\text { Mol } \\
\text { (Belgium) }\end{array}$ & $\begin{array}{l}\text { Belleville } \\
\text { (France) }\end{array}$ & $\begin{array}{l}\text { Wellesbourne } \\
\text { (U.K.) }\end{array}$ & $\begin{array}{c}\text { Jülich } \\
\text { (Germany) }\end{array}$ & $\begin{array}{c}\text { Barcelona } \\
\text { (Spain) }\end{array}$ \\
\hline FAO classification & orthic podzol & fluvisol & eutric fluvisol & orthic luvisol & calcic luvisol \\
\hline Soil texture & (Loamy) sand & Loamy sand & Sandy loam & Silt loam & Loam \\
\hline $\begin{array}{r}\text { Particle size } \\
\% \text { clay }\end{array}$ & 4.1 & 5.8 & 9.5 & 11.2 & 13.9 \\
\hline$\%$ silt & 14.6 & 13.7 & 19.7 & 78.8 & 28.8 \\
\hline$\%$ sand & 78.4 & 79.0 & 66.6 & 8.4 & 47.7 \\
\hline $\begin{array}{l}\text { Chemistry } \\
\text { pH (KCl) }\end{array}$ & 4.6 & 4.1 & 6.3 & 7.1 & 7.3 \\
\hline$\%$ organic matter & 3 & 1.5 & 3.9 & 1.5 & 2.3 \\
\hline Total carbonates (\%) & $\approx 0$ & $\approx 0$ & 0.3 & 0.2 & 7.2 \\
\hline $\operatorname{RIP}\left(\mu \mathrm{eq} \mathrm{g}^{-1}\right)$ & 443 & 1126 & 2316 & 2328 & 2732 \\
\hline $\mathrm{CEC}\left(\mathrm{cmol}_{\mathrm{c}} \mathrm{kg}^{-1}\right)$ & 11.7 & 5.8 & 17.8 & 13.4 & 16.4 \\
\hline
\end{tabular}

In order to do this, the base of the soil monolith rests upon a bed of porous ceramics, which are directly mounted on the water tank. The control of the 


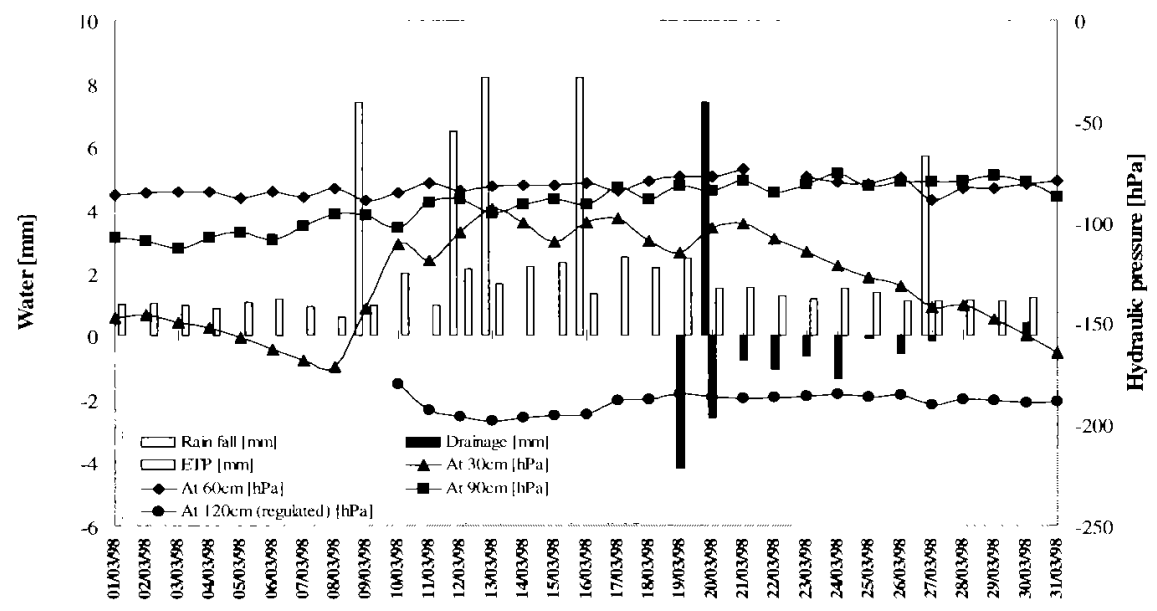

Figure 5-Hydraulic profile continuous follow up in a lysimeter soil with hydraulic pressures being measured at various depths.

Suivi continu du profil hydrique dans un sol en lysimètre sur la base de mesures de la pression hydraulique à différentes profondeurs.

hydraulic pressure (negative) in this tank enables the deep soil moisture to be controlled using a tensiometer located at the base of the monolith $(-120 \mathrm{~cm})$. Three other tensiometers were implemented at different depths $(-90,-60,-30 \mathrm{~cm})$ in such a manner as to obtain real time development of hydrological profiles (Fig. 5).

\subsubsection{Cultivations in the controlled lysimetric facility under greenhouse}

The preliminary tests were conducted to check that the growth and yield of the cultivation carried out under controlled conditions on the lysimeters were not very different from that obtained in situ. Wheat, clover and ray-grass were examined, offering agronomical characteristics that are at least equivalent to the averages observed in the original regions. In addition to this, the examination of the chemical composition in the plants' mineral constituents cultivated on the lysimeters has not shown any deficiency for the major elements, therefore verifying that the controlled lysimeters greenhouse assembly correctly simulates natural conditions.

\subsubsection{Radioactive aerosols produced by the contamination device POLYR}

Several test campaigns were carried out to characterise in detail ${ }^{137} \mathrm{Cs}$ and ${ }^{90} \mathrm{Sr}$ aerosols produced by the contamination device POLYR (Madoz-Escande et al., 1996). The average particles size emitted is around $3.5 \mu \mathrm{m}$. The recovery levels in 
aerosol form of elements present in the initial mix reaches $17.5 \%$ for the ${ }^{137} \mathrm{Cs}$, $15.5 \%$ for the ${ }^{90} \mathrm{Sr}$ (zero recuperation of $\mathrm{Ru}$ ). The solubility in rainwater of aerosol-caesium is much quicker than that of the aerosol-strontium, with levels reaching $95 \%$ after 24 hours for the first and $85 \%$ after 5 hours for the second. The chemical characterisation of aerosols produced show the presence of $\mathrm{CsI}, \mathrm{Sr}(\mathrm{OH})_{2}$ and many oxides. Finally, a study of radionuclide aerosols deposits on soil surfaces and on the canopy shows that these are spatially heterogeneous, at a factor of 2 to 3 on one same surface. Furthermore, deposits are shown to be generally higher, the rougher the surface under consideration (bare soil, leaves, filter papers).

\section{Scientific overview}

In an accidental situation with radioactive pollution of the agricultural environment, the consequences are to be assessed as a function of its potential to reach man by external exposure and by ingestion through the food chain. Where the food chain is concerned, the transfer pathways and their intensities differ as a function of the time elapsed after contamination. In the short term, the risk is basically linked with foliar transfer that establishes itself in cultivations that were on-site at the time of deposit. In the long term, from the moment of the first cultivation rotation, contamination of agriculture surfaces is found at soil level, in such a manner as the risk stems from transfers in soil and through root uptake.

\subsection{Radioecological foliar parameters}

\subsubsection{Study of a wheat cultivation}

The radioecological foliar data recorded for this cereal was reported by MadozEscande et al. (1996) and Vandecasteele et al. (2000). It is summarised in Figure 6. Measured immediately after dry contamination of wheat canopies, which have been cultivated beforehand up to different development stages, the foliar interception linearly increases with foliar surface (itself linked to the development stage), up to $80 \%$ at maturity, similarly for both radioelements. Examination of the foliar retention after the first rain ( 7 days after contamination) shows that the development stage at which the plants were contaminated has practically no influence: the leaching strength of radionuclides intercepted beforehand by the leaves remains identical. However, the leaching of caesium is high from the time of the first rain, and more intense (around $50 \%$ of intercepted activity) than that of strontium (around $20 \%$ of intercepted activity). Finally, the translocation to the wheat seeds and envelopes obtained at harvest is found to be clearly influenced by the development stage of plants at the time of contamination. The wheat seeds and envelopes are more contaminated for plants that were more developed at the time 


\section{EXPERIMENTAL DETERMINATIONS TO SUPPORT PREDICTIONS}
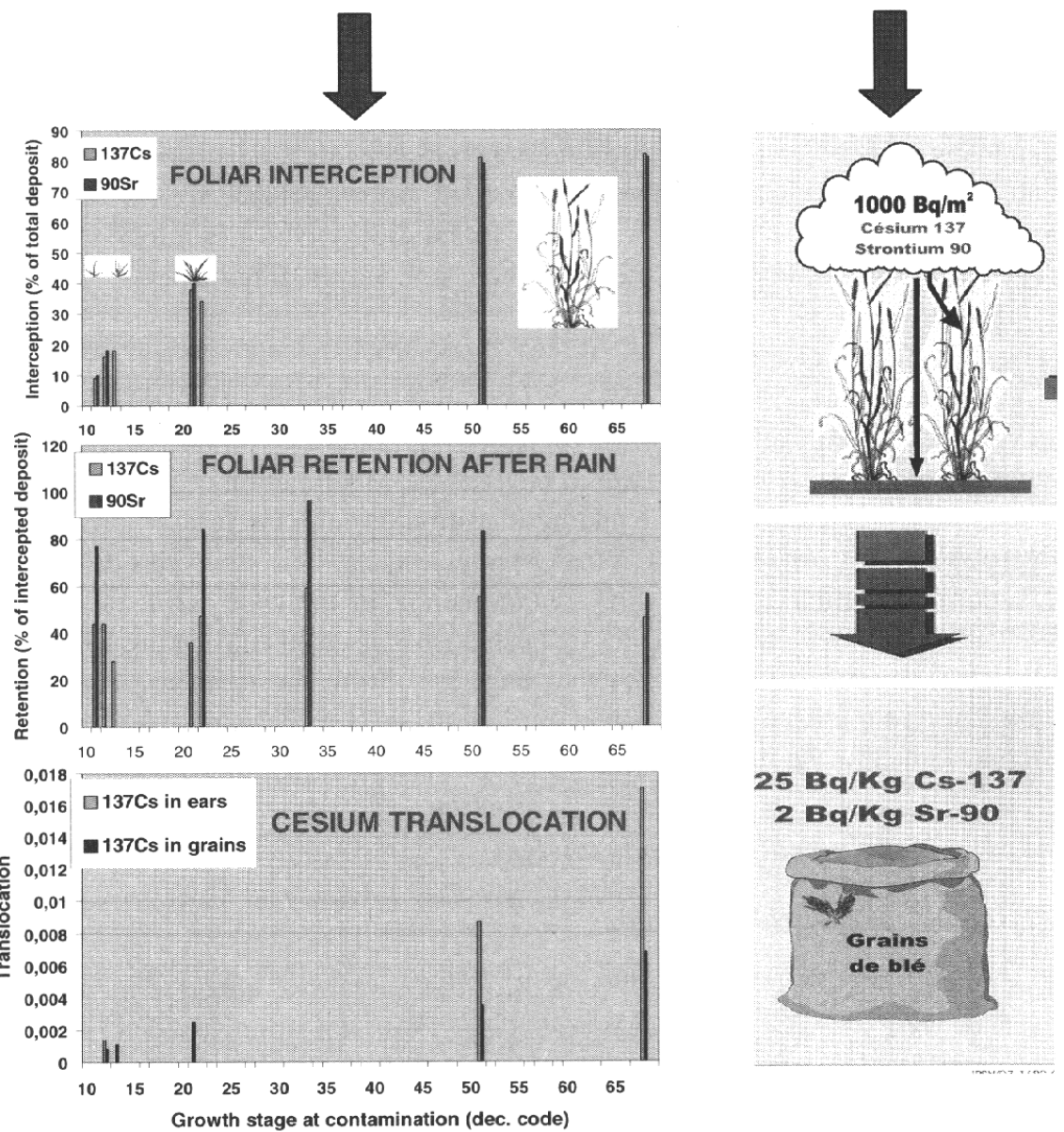

Figure 6 - Determination of foliar radioecological parameters for ${ }^{137} \mathrm{Cs}$ and ${ }^{90} \mathrm{Sr}$ - interception, retention, translocation - on a wheat crop at various stages of development (growth stage as a decimal code up to 100 corresponding to senescence).

Détermination des paramètres radioécologiques foliaires pour le ${ }^{137} \mathrm{Cs}$ et le ${ }^{90} \mathrm{Sr}$-interception, rétention, translocation - pour une culture de blé à différents stades de développement (stades de développement exprimés selon un code décimal atteignant 100 au stade de sénescence).

of their contamination. However, the absolute contamination levels are higher for caesium than for strontium (factor 10), indicating a tendency of caesium for internal translocation in the plant clearly higher than that of strontium. 


\subsubsection{Study of vine plants}

The vines, contaminated at the "end of flowering" stage, showed an interception coefficient of the initial deposit by the foliage of around $40 \%$ for both radionuclides. In the same manner as for wheat, the retention rate after the first rain of the initial contamination intercepted by the foliage is higher for strontium than for caesium, reaching $58 \%$ and $45 \%$, respectively. The leaching of caesium onto the soil is therefore greater as the ${ }^{137} \mathrm{Cs} /{ }^{90} \mathrm{Sr}$ ratio decrease through time on leaves shows. Finally, the intensity of transfers within the plant by means of translocation has been studied following the appearance of ${ }^{137} \mathrm{Cs}$ and ${ }^{90} \mathrm{Sr}$ contamination in organs (leaves and bunches) which had been protected beforehand from the direct aerosol deposits. This translocation is high from the 2 nd day after contamination, and then continues with a higher accumulation of ${ }^{137} \mathrm{Cs}$ in the bunches, as the slight increase in the ${ }^{137} \mathrm{Cs} /{ }^{90} \mathrm{Sr}$ ratio shows which evolves from 1 ( 2 days after contamination) up to 13 (at harvest, 30 days after contamination). The results obtained enable to assess that for a contamination at the "start of seed maturity" stage, the contamination of bunches of grapes at harvest results at $90 \%$ from the direct deposit of ${ }^{90} \mathrm{Sr}$ and at $50 \%$ from the direct deposit of ${ }^{137} \mathrm{Cs}$ (the rest being brought through translocation), (Madoz-Escande et al., 1997; 1998).

Non-lethal leaf removal was suggested as a remediation method intended to minimise contamination by translocation from the leaves (Jouve et al., 1994; Arapis et al., 1995). However, its application on the grapevine plants 7 days after contamination has not produced any appreciable reduction in bunch contamination (Madoz-Escande et al., 1997). That this may be more efficient in the event of early application is however not excluded. Finally, wine growing tests were undertaken from thus contaminated raisin juice, showing a decrease in the wine of around $30 \%$ for caesium and even higher for strontium. The wine yeast-deposit, eliminated in the final wine-growing phase, contains mass activities greater than those in the juice.

\subsection{The soil-radionuclide interactions}

\subsubsection{Composition of the ground water}

An interesting study reported by Kirchner and Elkhen (1997) on the pastures of North Germany suggested that root absorption of caesium and strontium was controlled by their respective concentrations in interstitial water in the soil, concentrations that were observed to increase with a reduction of soil moisture. Our study using in vitro experiments seems to confirm this tendency, as it shows that a reduction in soil moisture triggers a high increase in ${ }^{137} \mathrm{Cs}$ concentration in 
${ }^{134}$ Cs Soil solution

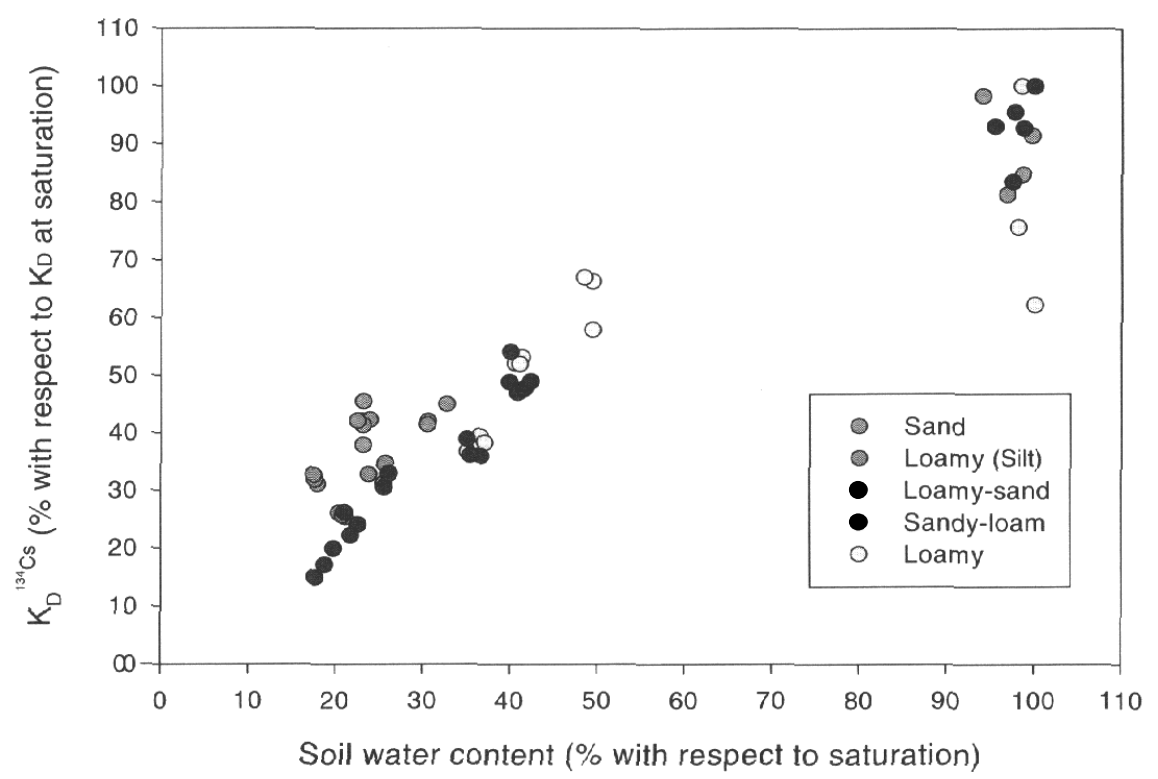

Figure 7 - Influence of soil moisture on the $K_{D}$ coefficient for caesium.

Influence de l'humidité du sol sur le coefficient $K_{D}$ pour le césium.

the ground water, therefore a reduction of $K_{\mathrm{D}}\left({ }^{137} \mathrm{Cs}\right)$, that may benefit root absorption (Fig. 7). However, soil moisture also influences other ionic concentrations, with an even stronger effect on potassium (K), in such a manner that the caesium to $\mathrm{K}$ ratio $(\mathrm{Cs} / \mathrm{K})$ is lower for reduced soil moisture. The root absorption of caesium results, in all likelihood, from a combination of both. A very similar behaviour, although less clear, was observed for strontium (and calcium) concentration in the ground water (Sauras et al., 1999; Bréchignac et al., 2000).

Considering its foreseeable implications on the intensity of root absorption, the influence of soil moisture on the $K_{\mathrm{D}}$ coefficient deserves to be taken into account in the models. Verification of the consequences of such a result on the contamination of plants observed in situ, on the lysimeter soil in place, has been obstructed by the existence of a spatial variability overshooting the temporal variability linked with soil moisture (climatic variations). In addition to this, it was otherwise shown (see Sect. 4.3.1.) that an increase in $\mathrm{K}$ concentration in the ground water reduced root absorption of caesium (competitive effect at the root 


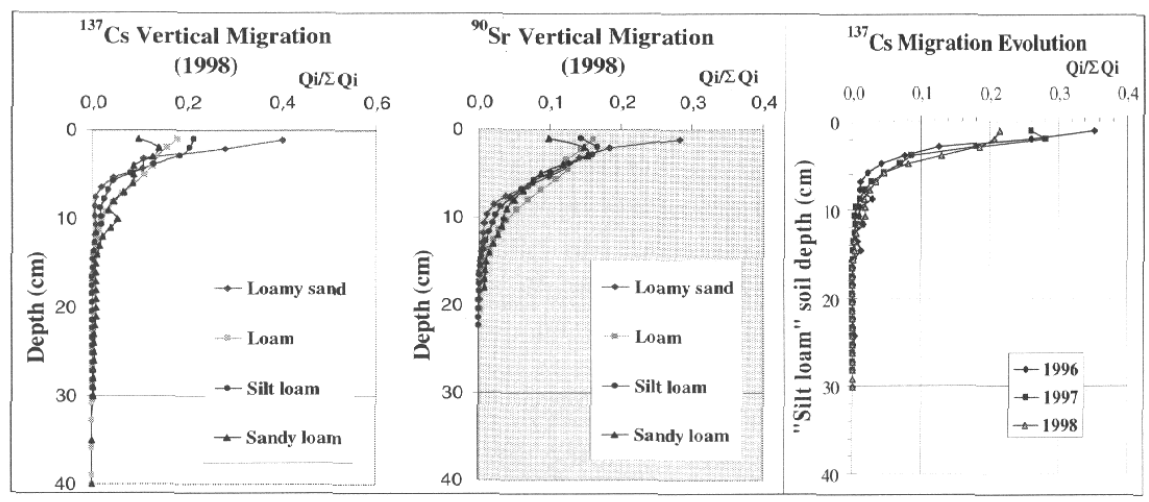

Figure 8- ${ }^{137} \mathrm{Cs}$ and ${ }^{90} \mathrm{Sr}$ migration profiles as measured on different soil types (4 years after contamination) and their development with time.

Profils de migration du ${ }^{137} \mathrm{Cs}$ et du ${ }^{90} \mathrm{Sr}$ mesurés sur différents types de sols (4 ans après contamination) et leur évolution au cours du temps.

transporters level), in such a manner as the influence of soil humidity on plant contamination in situ may be hidden. These results show, nevertheless, the key role played by the composition of ground water to understand the behaviour of radionuclides in the soil-plant system (Bréchignac et al., 2000).

\subsubsection{Vertical migration on unploughed soil}

The annual follow-up of vertical profiles of ${ }^{137} \mathrm{Cs}$ and ${ }^{90} \mathrm{Sr}$ in unploughed zones of the lysimeter soils confirms the slowness of this process in all mineral soils under consideration in this study (sand, loamy-sand, sandy-loam, loam and silt loam; Forsberg et al., 2000): 4 years after contamination, the two radionuclides remained mainly confined in the first 5 five centimetres of the soil (Fig. 8). A more detailed analysis however reveals new information (Bréchignac et al., 2000; Gonze and Bréchignac, 2000). Although ${ }^{137} \mathrm{Cs}$ and ${ }^{90} \mathrm{Sr}$ show different mobilities in view of their respective $K_{\mathrm{D}}$ values in each soil, their migration profiles remain quite similar. In addition to this, their migration rates observed from year to year $(1 \mathrm{~cm} /$ year, on average) are not in agreement with the shape of the profiles predicted by the models (based on the $K_{\mathrm{D}}$ concept). As other results obtained on soil columns confirm (where an enforced hydrological regime was applied with the aim of stimulating migration), it appears that these migration profiles establish themselves very quickly after the contamination event (Marchant et al., 1998), with very limited subsequent development. It is concluded that the establishment of migration profiles is largely conditioned by initial climatic conditions immediately following the contamination event (status of soil moistening and rain). 


\subsubsection{Spatial distribution on ploughed soil and chemical availability}

These measurements were undertaken in the aim of supporting the determination of soil-to-plant transfer factors through precise knowledge of the distribution of radionuclides in the ploughed horizons (Aoustin, 1998). This enables, in particular, to show that after an aerosol deposit on the surface, the contamination distribution becomes homogeneous in the first twenty centimetres after 3 conventional ploughs (performed manually with a spade). In this horizon, the chemical availability of radionuclides evaluated by extraction with ammonium acetate $1 \mathrm{~N}$ (around $15 \%$ for ${ }^{137} \mathrm{Cs}$ and $50 \%$ for ${ }^{90} \mathrm{Sr}$ ) does not develop with time in a significant manner, and is found to be in respective agreement with the exchangeable fractions of $\mathrm{K}$ and $\mathrm{Ca}$ in the different soils (Forsberg et al., 2000; Madoz-Escande et al., 2000).

\subsection{Radioecological root parameters - soil-to-plant transfers}

Contrasted plants were studied in this programme: ligneous perennial plants (the vines), herbaceous perennial plants (ray-grass and lucerne), annual agricultural plants (winter barley, beans, lettuce). The vines were studied separately on the 2 lysimeters sampled at Tricastin. The other plants are cultivated in parallel on the 5 other soils (Belleville, Mol, Wellesbourne, Barcelona and Jülich) in order to gain knowledge of the influence on variability of transfers for parameters such as soil type, climate, agricultural practices and the time elapsed after contamination.

\subsubsection{Annual and herbaceous plants}

\section{Influence of soil type and climate}

The classification of transfer factors observed is often not agreeing with the sole physico-chemical characteristics of the different soils (Tab. I, Fig. 9), as it also depends on soil productivity, and plant growth that is itself subjected to climatic conditions. The influence of soil type and climate on the soil-to-plant transfer thus, essentially acts through the chemical composition of the ground water and the physiological characteristics of the plants (Sauras et al., 1998, 1999; Bréchignac et al., 2000). K content and growth are determining factors for caesium transfer, whereas $\mathrm{Ca}$ content and transpiration are determining factors for the transfer of strontium (Casadesus et al., 1999).

Similarly, the classification of transfer factors for caesium does not always agree with the sole retention characteristics for the different soils $\left(R I P^{35}\right.$ linked to

53 RIP: Radiocaesium Interception Potential. 

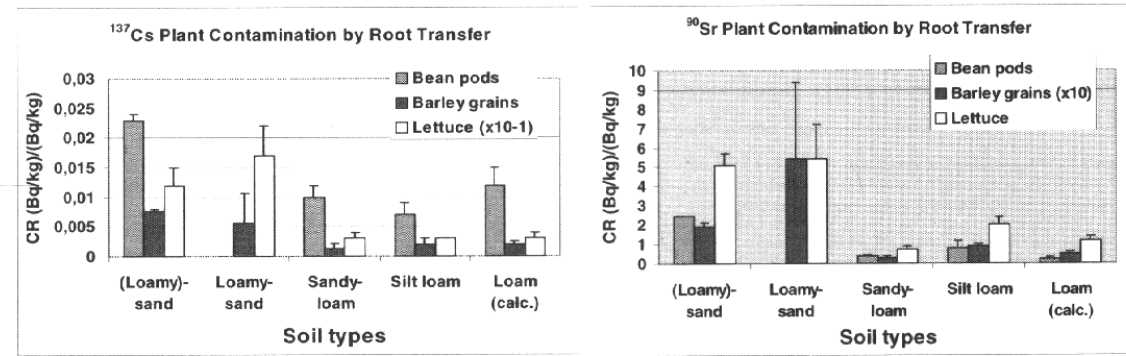

Figure $9-{ }^{137} \mathrm{Cs}$ and ${ }^{90} \mathrm{Sr}$ root transfer (as concentration ratios) obtained on five distinct agricultural soils for lettuce, bean pods and barley grains.

Transfert racinaire du ${ }^{137} \mathrm{Cs}$ et du ${ }^{90} \mathrm{Sr}$ obtenus sur 5 différents sols agricoles pour la laitue, les gousses de haricot et les grains d'orge.

$K_{\mathrm{D}}$ Cs: Sweeck et al., 1990; Wauters et al., 1994). Taking into account the K concentration in the ground water improves the explanation of the observed variations, in particular for soils with a fine texture (high RIP). It appears that for short rotation cultivation (beans and lettuce), the transfer factor is quite well predicted by the $C F / K_{\mathrm{D}}$ ratio (with $C F$ : concentration factor with respect to the ground water), as the $\mathrm{K}$ variations in the soil remain small on this time scale. For longer cultivations (barley), $\mathrm{K}$ concentration in the ground water may be near to zero, in particular for soils with a low buffer capacity in $\mathrm{K}$, and stimulates the activation of active root transporters with greater affinity, which means increased transportation of caesium.

\section{Development with respect to time}

The influence of time may be addressed at several different scales. The transfer of radionuclides to plants undergoes variations featuring low time characteristics, during the development cycle (Sauras et al., 1999). These variations may be explained on a physiological basis (root transporter activations with different affinities) or based on modifications of the ground hydrological conditions (governed by the climate). From one year to the next, the observed variations may still arise more from modifications of the composition of the ground water (in particular under the influence of fertilising treatments) than from manifestations of an "ageing" (evolution of chemical availability for example), (Waegeneers et al., 1998, 2001). In the longer term, on soil that has not been reworked (ray-grass cultivations on unploughed soil), the above-mentioned variations are still underway, but overlap with a slow decrease of the rate of transfer for which the biological period is consequently difficult to accurately estimate over an observation time reduced to a few years only. Experiments on lysimeters that are reported here enable however the demonstration that this 


\section{F. BRÉCHIGNAC et al.}

biological period is definitely greater to one year. For caesium, the gradual decrease of long-term transfers is most often attributed to its slow, irreversible fixation in the clay (illite) interlayers.

\section{Agricultural practices}

The influence of traditional agricultural practices affects only slightly and in a similar manner the bioavailabilities of caesium and strontium. Considering the ground water, repeated additions of fertilisers ( $\mathrm{K}$ in particular) produce two opposite effects which overlap: they reduce the plant's affinity for caesium uptake (reduction of the concentration factor, $C F$ ) whilst increasing its availability in the ground water (reduction of $K_{\mathrm{D}} \mathrm{Cs}$ ). According to the $\mathrm{K}$ concentration range in effect at root contact, one or another of the effect dominates the transfer (Gonze and Bréchignac, 2000; Bréchignac et al., 2000). In general, the bioavailability depends more on the influence of analogues on the radionuclide availability than the total activity of these latter in the soil.

\section{Inter-plant variability}

In general, ${ }^{90} \mathrm{Sr}$ transfer rates are always stronger than ${ }^{137} \mathrm{Cs}$ ones, regardless of the soil type (under consideration in this study). The plants' different physiologies and anatomies as well as the variety of their organs with agronomical value (leaves, roots or seeds) determine their different propensity to the accumulation of radionuclides. For example, the accumulation is stronger in the leaves than it is in the seeds/fruits (where transfer must complete an additional translocation stage). In a radioprotection perspective, the reduction of the bioavailability of radionuclides in the agricultural system relies upon an appropriate choice of the crop plant-fertilising couple.

\subsubsection{Ligneous plants - Grape vines}

After the first year (1994, date of the accidental simulation) where the grape seeds are found to have been contaminated by foliar route, the harvests of the next years (from 1995 and further on), then subjected to root transfer only, were followed up. The massic contamination in ${ }^{137} \mathrm{Cs}$ of grape seeds regularly decreases from year to year, whereas the massic contamination in ${ }^{90} \mathrm{Sr}$ increases for several years before becoming stable (Fig. 10) a feature which clearly stands out against the results observed on perennial herbaceous plants. The massic contamination of leaves shows developments that are very similar. The increase from year to year in ${ }^{90} \mathrm{Sr}$ in the bunches and leaves seems to result from a gradual increase in its availability in the soil, but it may also arise from a slow emptying, by translocation, of a pool accumulated in the wood at the time of contamination (Madoz-Escande et al., 1998). 


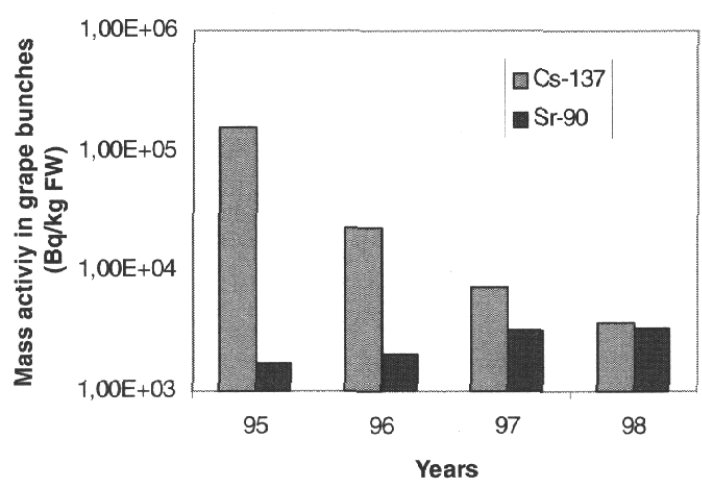

Figure 10 - Contamination development in grape bunches from the first year after contamination and further on.

Évolution de la contamination des grains de raisin au cours du temps à partir de la première année après la contamination.

\subsection{Mechanistic modelling of transfers in the soil-plant system}

\subsubsection{Migration (PHAST and TRANSSOL models)}

Although simulating water flux in the soil-plant system in quite a remarkable manner, as indicated by the confrontation with the experimental measurements in the lysimeters, the migration modelling (undertaken initially according to 2 separate models, PHAST and TRANSSOL) shows that the conventional formulation based on the $K_{\mathrm{D}}$ (as usually determined, i.e. in vitro) does not enable a satisfactory prediction of the observed profiles, even when taking into account the influence of soil moisture demonstrated elsewhere (Gonze, 1999; Gonze and Bréchignac, 2000; Marchant et al., 1999). The teachings drawn from the development of these models show that it would be advisable to formulate migration based on a "global retention coefficient" that takes into account not only the $K_{\mathrm{D}}$ (as influenced by the composition of the ground water) but also the soil structure (particle aggregation) and the kinetic characteristics of the sorption and desorption of radionuclides. It is finally suggested that in-depth penetration observed for both radionuclides may also be influenced by a transport via colloids, by an initial early migration linked to non-instantaneous dissolution rates of aerosols (strontium in particular), or even by an increasing reverse flux resulting from the root absorption activity, which the models under consideration do not take into account.

\subsubsection{Root absorption (RUR model)}

This model's objective consists of taking into account the influence of plant physiology on the root absorption processes that determine the transfer of caesium 
and strontium present as traces. This model, derived from the conventional Barber and Cushman model (1981) considers that caesium and strontium are absorbed at root level by the membrane ionic transport systems of $\mathrm{K}$ and $\mathrm{Ca}$, respectively (Roca Jové et al., 1998). The developments of this modelling have enabled the identification of essential parameters that govern transfers at this interface. The caesium absorption depends especially on the one hand on $\mathrm{K}$ content of the ground water and on the $K_{\mathrm{D}} \mathrm{Cs}$, and on the other hand, on the accumulated biomass (growth) as well as the development of the root system. Strontium absorption is especially driven by $\mathrm{Ca}$ content in the ground water (in particular, for young plants), and by transpiration (especially for mature plants characterised by a strong leaf development and reduced growth rates), (Casadesus et al., 1999).

The TRANSSOL model, initially designed to simulate migration only, has recently evolved towards taking into account root absorption (by integrating a simplified version of the root absorption model) in such a manner as to describe all transfers in the soil-plant system.

\section{Knowledge transfer towards operational prediction}

The implications for radioprotection of the results of this research may be summarised as follows.

- Composition of the ground water is a central point to solve the variability of root transfer of radionuclides in plants. If the soil type, agricultural practices, weather and climatic conditions (soil moisture) parameters all promote a variability of the transfer factors, this is essentially performed through their effects on the composition of the ground water, with, in particular, concentrations in $\mathrm{K}, \mathrm{Ca}$ and $\mathrm{Mg}$ analogues. This aspect should notably guide operational modelling in its efforts to define a geographical zone as according to radioecological sensitivity criteria.

- The description of soil according to the conventional $K_{D}$ concept does not enable correct prediction of vertical migration. The $K_{\mathrm{D}}$ is a partition coefficient between the solid matrix and the ground water which is most often measured in vitro (soil structure destroyed), generally at water saturation, and after the equilibrium is reached. However, $K_{\mathrm{D}}$ depends on analogue concentrations (composition of the ground water) and integrates neither soil structure nor kinetic characteristics of sorption and desorption. This results in that models cannot simply rely on the conventional $K_{\mathrm{D}}$ but should rather involve a "global retention coefficient" integrating this complexity.

- The importance of early climatic conditions on the migration furthers to contamination. The profiles are established in less than one month, with a very limited further development. During this early phase, it seems probable that the soil moisture conditions and the very first rains largely determine the 
establishment of the profiles, the soil not having yet reached its maximum retention capacity (macropores, preferential pathways, non-instantaneous dissolving).

- The importance of early climatic conditions on foliar transfers following contamination. Given the foliar experiments undertaken during this research, the influence of the first rain appears a determining factor on the subsequent intensity of translocation towards consumable organs (this was only examined after a 7-day delay between contamination and the first rain). However, it is not impossible that a shorter delay may increase the leaf leaching intensity and finally, the final translocation. In addition to this, the near universal use of phytosanitory products called "systemic" that is to say containing additives that aid the penetration of active substances into foliar cuticles, has not been studied in a radioecological perspective. In such conditions, it may appear clear that the transfer coefficients of radionuclides by foliar pathway may be stimulated.

- Operational models benefit from knowledge gained by mechanistic models, in particular, in identifying the process fields where simplification is justified and those where a better description is required in order to orient the simplifications. In the aim of an optimised description of bioavailability, TRANSSOL identifies the requirement of better understanding of the phenomena that determine global retention by the soil, and the root absorption model identifies the importance of the plant mineral absorption physiology on the composition of the ground water.

- The acquired knowledge on the soil-to-plant transfer supports the aid for post-accidental intervention management: give priority to plants/species showing the lowest transfer rates (cereals, for example) and use the remedial capacity of fertiliser addition when the soil type under consideration will allow it.

- Improvement of long-term previsions resting firstly on a better understanding of "bioavailability" rather than on the detailed taking into account of intermittent climatic events or soil types. It appears, besides, that the spatial variability is more important than temporal variability.

\section{Conclusion}

It is important to highlight the originality of the lysimetric instrumentation of IPSN, for which no equivalent exists in Europe, and which has pioneered new facilities such as the ACEF (Artificial Climate Experiment Facility) recently constructed in the Radioecology Department of the Institute for Environmental Sciences, located at the Aomori prefecture in Japan (Kondo, 1997). It enables the simulation of accidents promoting radioactive contamination in a safe controlled context, on representative environmental samples - the soil monoliths in 
lysimeters - carried out in environmental conditions that are or both realistic (climates, hydrological conditions) and controlled, that is to say well-known. Such an approach largely fills up the inherent gaps of the experiments carried out in natural accidentally contaminated zones, which justifies the facility operating cost and the large constraints driven by its extensiveness.

This report was drafted based on the first flux of experimental results which have concentrated the analysis work, and which have, to date, given rise to publications or announcements in international congresses. The experimental database, acquired during these programmes under controlled conditions, is rich and well documented. It will continue to be the object of scientific exploitations that are as precious as they are promising, in particular for validation and improvement of current forecasting models. A global preview of the range of the latest scientific investigations undertaken may be found in the final report at the European Community of the European PEACE project which was completed at the end of 1999 (Bréchignac et al., 1999).

Up to now, the results shown here in the form of a synthetic report have enabled identification of new lines of research which are currently implemented in the aim of reinforcing the relevance of current strategies designed to stand up to radiological environmental contamination situations. Amongst these lines, soil microbiological processes are more seriously taken into account that very probably affect the speciation of radionuclides, their migration (at least due to their aggregating action on the soil structure), as well as the root absorption physiology (mycorhizae, in particular). In matters of accidental situations, the importance of immediate early conditions is underlined, where the still unknown kinetics develop, both at the foliar transfer level as that of migration in the soil (that then influences future root transfers). Finally, as the biological half-lives of radionuclides are generally lower in the human organism than in the environment as a means of support for diet, it is this latter that imposes its influence on the potential exposure of man. Therefore, it emerges that the slow kinetic environmental processes, all the more difficult to quantify as they take a long time to manifest themselves in a tangible manner, deserve close attention which should be actively supported through modelling. This aspect is particularly echoed in chronic exposure situations where the multipollution context has rarely been dealt with even though it is the usual rule in the environment (Bréchignac et al., 2000).

Acknowledgements. The implementation of this research was possible thanks to the both moral and financial support of Electricite de France and the European Commission (DG XII). Their almost permanent commitments, despite errors inherent to the development of projects subject to extensive instrumentation, has resulted in the assets for success for this enterprise. Through the researchers and 


\section{CONTROLLED LYSIMETRIC SIMULATION OF ACCIDENTS}

high quality technicians that they have made available to this project, several European Laboratory have contributed to building the substance of the report that has been able to be drafted here. Enriched scientifically as much as personally by all these collaborations, the authors wish to thank: G. Arapis, S. Baker, J. Branson, O. Burton, A. Butler, V. Camilleri, J. Casadesus, C. Colle, E. Dubois, S. Escavis, S. Forsberg, H. Förstel, J. Gutierrez, J. Hugon, K. Johansson, A. Jouve, H. Juhan, R. Kirchmann, J. Marchant, H. Maubert, R. Millán, M. Morello, M. Muszinski, K. Nicholson, C. Roca, L. Romero, P. Rongier, S. Roussel-Debet, K. Rosén, A. Sanchez, J. Sandalls, T. Sauras-Yera, G. Shaw, A. Stacey, S. Staunton, M. Strandmark, Y. Thiry, J. Tompkins, J. Tormos, E. Valke, R.V. Vallejo, C. Vandecasteele and N. Waegeneers.

\section{REFERENCES}

Aoustin E. (1998) Spatial distribution of ${ }^{137} \mathrm{Cs}$ and ${ }^{90} \mathrm{Sr}$ in contaminated german experimental ploughed soil, in Proceedings of "Environmental Engineering Research Event 1998; Environmental Engineering in Australia: Opportunities and Challenges", A.I. Schäfer, L. Basson, B.S. Richards (Eds.), December 6-9, 1998, Avoca Beach, New South Wales, Australia, pp. 117-122.

Arapis G. (1995) Reduction of radiocontamination on agricultural crops by the method of "non-lethal defoliation", in Proceedings of the 4th International Conference on Environmental Science and Technology; September 4-7, 1995, Lesbos, Greece.

Barber S.A., Cushman J.H. (1981) Nitrogen uptake model for agronomic crops, in Modelling Waste Water Renovation - Land treatment, I.K. Iskandar (Ed.), Wiley Intersciences, New York, pp. $382-409$.

Bréchignac F., Colle C., Hugon J., Madoz-Escande C., Rongier P., Sanchez A. (1996) RESSAC: A research facility for studying radionuclides bchaviour within ecosystems, in Proceedings of IRPA International Congress on Radiation Protection. April 14-19, 1996, Vienna, Austria, Volume 3, pp. 137-139.

Bréchignac F., Rongier P., Hugon J., Dubois E.. Colle C.. Madoz-Escande C. (1997) Controlled lysimetric enviornmental facility at IPSN: assessing accidental radioaclive contamination, in Proceedings of the International Meeting on the Influence of Climatic Characteristics upon the Behaviour of Radioactive Elements, Ohmomo Y., Sakurai N. (Eds.), October 14-16, 1997 , Rokkasho, Aomori, Japan, pp. 35-42.

Bréchignac F., Vallejo R.V., Sauras-Yera T., Casadesus J., Thiry Y., Waegeneers N., Forsberg S., Shaw G., Madoz-Escande C., Gonze M.-A. (1999) PEACE: Programme for Evaluating the impact of Accidents Contaminating the Environment - Soil-radionuclides processes of interaction and modelling of their impact on contamination of plant food products, Final Report, European Atomic Energy Community Contract F14-CT96-0039a, IPSN-DPRE/SERLAB Report 99-017(P), 60 pages.

Bréchignac F., Thiry Y., Waegeneers N., Vallejo R., Sauras-Yera T., Casadesus J., Shaw G ., Marchant J., Forsberg S., Madoz-Escande C.. Colle C., Gonze M.A. (2000) Soil-radionuclides interaction and subsequent impact on the contamination of plant food products based on a simulated accidental source, in Proceedings of the SPERA 2000 Conference "Environmental Changes and Radioactive Tracers", June 19-23, 2000, Nouméa, New Caledonia, in press.

Bréchignac F., Moberg L., Suomela M. (20()) Long-term environmental behaviour of radiuonuclides - Recent advances in Europe, Final Report of the IPSN-CEC Association during the 4th Framework Programme of the European Atomic Energy Community, Mission Communication IPSN (Ed.), 65 pages. 


\section{F. BRÉCHIGNAC et al.}

Casadesus J., Sauras-Yera T., Roca C., Vallejo R.V. (1999) Root uptake model validation, Technical Note of the PEACE CEC contract No. F14P-CT96-0039a, 27 pages and Appendices.

Forsberg S., Rosén K., Fernandez V., Juhan H. (2000) Migration of ${ }^{137} \mathrm{Cs}$ and ${ }^{90} \mathrm{Sr}$ in undisturbed soil profiles under controlled and close-to-real conditions, J. Environm. Radioact. 50 (3), 235-252.

Forsberg S., Rosén K., Bréchignac F. (2001) Chemical availability of ${ }^{137} \mathrm{Cs}$ and ${ }^{90} \mathrm{Sr}$ in undisturbed Iysimeter soils driven under controlled and close-to-real conditions, J. Environm. Radioact. 54, 253-265.

Gonze M.A. (1999) Numerical simulations of ${ }^{137} \mathrm{Cs}$ and ${ }^{90} \mathrm{Sr}$ migration: TRANSSOL versus lysimeter experiments, Technical Note of the PEACE CEC contract No. F14P-CT96-0039a, 27 pages.

Gonze M.A., Bréchignac F. (2000) Modelling the fate of ${ }^{137} \mathrm{Cs}$ and ${ }^{90} \mathrm{Sr}$ in a soil-pant system: empirical versus physically-based approaches, International Workshop on the Distribution and Speciation of Radionuclides in the Environment, October 11-13, 2000, Aomori, Japan.

Grauby A. (1988) Les transferts de radioéléments dans la chaîne alimentaire, les enseignements de Tchernobyl, le programme RESSAC, Radioprotection 23 (2), 149-154

Jouve A., Maubert H., Bon P., Barthe P. (1991) Soil reclamation with turfing plant harvest, in Proceedings of the International Conference on Implications of the new ICRP recommendations on radiation protection parctices and interventions, Volume 2, November 26-29, Salamanca, Spain, pp. 361-367.

Jouve A., Maubert H., Schulte E.H. (1992) Bio-mechanical removing of contaminated soils: a field experiment, in Proceedings of the Symposium on Waste Management, March 1-5, 1992, Tucson, Arizona, USA, pp. 643-646.

Jouve A., Schulte E.H., Bon P., Cardot A.L. (1993) Mechanical and physical removing of soil and plants as agricultural mitigation techniques, Sci. Tot. Environm. 137, 65-79.

Jouve A., Maubert H., Millan-Gomez R., Kutlakhmedov Y. (1993) Rehabilitation of soils and surface after a nuclear accident : some techniques tried in the Chernobyl zone, in Proceedings of the 1993 International Conference on Nuclear Waste management and Environmental remediation, Volume 2, September 5-11, Prague, Czech Republic, pp. 391-396.

Jouve A., Cecille L., Kutlakhmedov Y., Grebenkov A., Davydchuk V., Maubert H. (1994) Decontamination strategies; presentation of the collaboration project between EC and CIS, in Proceedings of the International Symposium on Remediation and Restauration of Radioactivecontaminated Sites in Europe, European Commission, Radiation Protection, DGXI-5027/94, pp. 867-878.

Jouve A., Maubert H., Kutlakhmedov Y., Grebenkov A., Cécille L. (1994) CEC/CIS collaboration on the consequences of the Chernobyl accident; preliminary results on the project dealing with strategies of decontamination, in Proceedings of the Symposium on Waste Management, Volume 1, February 27 - March 3, Tucson, Arizona, USA, pp. 129-132.

Jouve A., Schulte E.H., Maubert H., Bon P. (1994) Non-lethal defoliation to impair the foliar uptake of fall-out radionuclides by forest trees, Sci. Tot. Environm. 157, 407-410.

Kirchner G., Ehlken S. (1997) Climatic influence on root uptake of Cs and Sr by pasture plants: evidence from field experiments in northern Germany, in Proceedings of International Meeting on Influence of Climatic Characteristics upon Behaviour of Radioactive Elements, October 1416, 1997, Ohmomo Y., Sakurai N. (Eds.), Institute for Environmental Sciences, Aomori, Japan, pp. 83-90.

Kondo K. (1997) Design of the artificial climate experiment facility (ACEF) of the Institute for Environmental Sciences, in Proceedings of the International Meeting on the Influence of Climatic Characteristics upon the Behaviour of Radioactive Elements, Ohmomo Y., Sakurai N. (Eds.), October 14-16, Rokkasho, Aomori, Japan, pp. 11-16.

Legrand B. (1988) Programme RESSAC (Réhabilitation de sols et des surfaces après un accident, in Actes du $4^{e}$ Symposium International de Radioécologie, 14-19 mars, Cadarache, France, pp. F90-F94.

Legrand B., Fache P., Camus H., Gauthier D., Hamoniaux M. (1989) Premiers résultats expérimentaux du programme RESSAC sur les essais in situ de décontamination/fixation et études de migration 


\section{CONTROLLED LYSIMETRIC SIMULATION OF ACCIDENTS}

des radionucléides dans les sols, in Proceedings of the International Colloquium on the operations for the restauration of normal conditions after a nuclear accident, November 6-10, Vienna, Austria.

L'Homme A., Parmentier N., Legrand B., Fache P. (1989) Presentation of the RESSAC Research Program (Rehabilitation of Soils and Surfaces after an Accident), in Proceedings of the International Colloquium on the operations for the restauration of normal conditions after a nuclear accident, November 6-10, Vienna, Austria.

Madoz-Escande C., Hugon J., Jouglet H. (1996) Caractérisation des contaminations des expérimentations effectuées en 1994-1995 dans le «bâtiment lysimètres », Rapport IPSNSERE 96-018 (P), 64 pages.

Madoz-Escande C., Colle C., Hugon J., Jouglet H., Tormos J. (1996) Contaminations foliaires de cultures de blé. Expérimentations 1994 sur un lysimètre de grande dimension extrait du site de Belleville, Rapport IPSN-SERE 96-029 (P), 26 pages.

Madoz-Escande C., Colle C., Hugon J., Jouglet H., Tormos J. (1997) Contaminations foliaires de culture de vigne. Expérimentations 1994-1995 sur des lysimètres de grandes dimensions extraits du site de Tricastin, Rapport IPSN-SERE 97-026 (P), 47 pages.

Madoz-Escande C., Colle C., Bréchignac F., Jouglet H., Fernandez V. (1998) Time-dependent evolution of ${ }^{137} \mathrm{Cs}$ and ${ }^{90} \mathrm{Sr}$ deposited as aerosols on vine, 8 th Annual Meeting of SETACEurope, April 14-18, Bordeaux, France.

Madoz-Escande C., Bréchignac F., Colle C., Dubois E., Hugon J., Jouglet H., Moutier M., Rongier P., Sanchez A., Schulte E.H., Zanon R. (1999) Experimental installation for radioecology research on defined ecosystems subjected to contamination in controlled conditions, Nucl. Sci. Engineer. 133,178-191.

Madoz-Escande C., Colle C., Adam C., Juhan H., Camilleri V., Blanc F., Magna P. (2000) Interactions sol-radionucléides : I- Comportement du ${ }^{137} \mathrm{Cs}$ et du ${ }^{90} \mathrm{Sr}$ dans les sols des lysimètres, Rapport IPSN-DPRE/SERLAB 99-026, in press.

Marchant J.K., Butler A.P., Shaw G., Tompkins G., Wadey J.A., Wheaters H.S. (1998) Observations of caesium-134 and strontium-85 migration in column experiments following surface contamination, XXVIIIth ESNA Annual Meeting, August 26-29, Brno, Czech Republic.

Marchant J., Butler A., Tompkins J., Shaw G. (1999) Column experiment results and related mathematical modelling (PHAST), Technical Note of the PEACE CEC contract No. F14PCT96-0039a, 20 pages.

Maubert H., Schulte E.H., Jouve A. (1991) RESSAC: Rehabilitation of soils and surfaces after an accident : a european research program for remediation of radioactive contamination, in Cleaning up the Environment for the 21st Centur, Environmental Remediation'91, September 8-1 I, Pasco, Washington, USA, pp. 713-716.

Maubert H., Fache P., Jouve A., Rongier P., Schulte E.H. (1992) Le programme RESSAC : bilan et perspectives, Rev. Gén. Nucl. 2, 140-142.

Maubert H., Jouve A., Mary N., Millan-Gomez R. (1992) Agricultural soil decontamination techniques: methods and results of tests realised near Chernobyl, in Séminaire commun SFRPFS: Impact des installations nucléaires sur l'environnement, 15-18 septembre, Fribourg, Suisse, pp. 493-497.

Maubert H., Vovk I., Roed J., Arapis G., Jouve A. (1993) Reduction of soil-plant transfer factors: mechanical aspects, Sci. Tot. Environm. 137, 163-167.

Renaud P., Maubert H. (1997) Agricultural countermeasures in the management of a post-accidental situation, J. Environ. Radioact. 35, 53-69.

Roca Jové M.C., Vallejo Calzada V.R. (1998) Preticting radiocaesium and potassium root uptake using the Barber-Cushman model, XXVIIIth ESNA Annual Meeting, August 26-29, Brno, Czech Republic.

Sauras T., Vallejo V.R., Valcke E., Colle C., Förstel H., Millàn R., Jouglet H. (1998) ${ }^{137} \mathrm{Cs}$ and ${ }^{90} \mathrm{Sr}$ root uptake under close to real controlled conditions, 8th Annual Meeting of SETAC-Europe, April 14-18, Bordeaux, France. 


\section{F. BRÉCHIGNAC et al}

Sauras-Ycra T., Vallejo V.R., Valcke E., Colle C., Förstel H., Millàn R., Jouglet H. (1999) ${ }^{137}$ Cs and ${ }^{90} \mathrm{Sr}$ root uptake under close to real controlled conditions, J. Environm. Radioact. 45 (3), 191-218.

Sauras T,, Vallejo R., Waegeneers N., Thiry Y. (1999) Dynamics of soil-radionuclides interaction, Technical Note of the PEACE CEC contract No. FI4P-CT96-0039a, 20 pages.

Sauras T., Casadesus J., Roca C., Vallejo R. (1999) Soil-to-plant transfer for barley crop: influence of plant growing stage, soil physico-chemical properties and agricultural practices, Technical Note of the PEACE CEC contract No. F14P-CT96-0039a, 29 pages.

Strand P., Balonov M., Skuterud L., Hove L., Howard B., Prister B.S., Travnikova I., Radnikov A. (1996) Exposures from consumption of agricultural and semi-natural products, in The Radiological Consequences of the Chernobyl Accident, Karaoglou A., Desmet G., Kelly G.N., Menzel H.G. (Eds.), Eur 16544, EN-Luxembourg, pp. 261-269.

Sweeck L., Wauters J., Valcke E., Cremers A. (1990) The specific interception potential of soils for radiocaesium, in Transfer of radionucides in natural and semi-natural environments, Desmet G., Nassimbeni P., Belli M. (Eds.), Elsevier Science Publishers, Brussels and Luxembourg, pp. 249-258.

Vandecasteele C., Baker S., Förstel H., Muszinsky M., Millan R., Madoz-Escande C., Tormos J., Sauras T., Schulte E.H., Colle C. (2001) Interception, Retention and translocation of radiocaesium and radiostrontium from a simulated accidental source, Sci. Tot. Environm., submitted.

Waegeneers N., Camps I Vila M., Smolders E., Merckx R., Sauras T., Madoz-Escande C. (1998) Uptake of radiocesium by lettuce crops: the effect of potassium in soil solution, XXVIIIth ESNA Annual Meeting, August 26-29, Brno, Czech Republic.

Waegeneers N., Thiry Y., Madoz-Escande C., Bréchignac F. (2001) Time does not always tend to reduce the ${ }^{137} \mathrm{Cs}$ soil-to-plant transfer-An examination of letluce crops grown on undisturbed lysimeter soils under close-to-real conditions, in preparation.

Wauters J., Sweeck L., Valcke E., Elsen A., Cremers A. (1994) Availability of radiocaesium in soils: a new methodology, Sci. Tot. Environm. 157, 239-248 